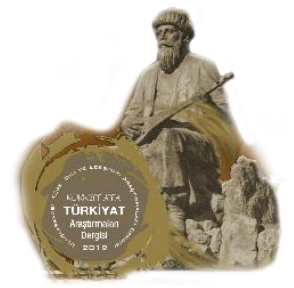

\author{
KORKUT ATA TÜRKIYYAT ARAŞTIRMALARI DERGİSI \\ Uluslararası Türk Dili ve Edebiyatı Araştırmaları Dergisi \\ The Journal of International Turkish Language \& \\ Literature Research
}

\title{
Adana İli, Şambayadı Köyü'nde Doğumla İlgili İnanç ve Uygulamalar Üzerine Bir İnceleme*
}

\section{A Review on The Rituals and Treatments about Birth in the Village of Şambayadı at Adana City}

Fazıl ÖZDAMAR**

Öz

\begin{abstract}
Adana ili, Çukurova ilçesine bağlı bir yerleşim birimi olan Şambayadı Köyü, adından da anlaşılacağı üzere Şambayadı Yörük/Türkmenleri tarafından kurulmuştur. Bu Türkmenler, doğumdan ölüme kadarki geçiş dönemlerindeki inanç ve uygulamaların yanında deyimatasözü, masal, fıkra, halk hikâyesi vd. sözlü kültür ürünlerini yerleşik hayata geçtikten sonra da muhafaza etmeye ve kullanmaya devam etmektedirler. Bu kültür unsurlarının yaşatılmasında söz konusu bölgenin kültürel etkiye kapalı olması etkilidir, denilebilir. Doğum günü kutlaması ve "gün yapma" gibi modern kültürün bazı unsurları dışında köy halkı dış dünyaya hemen hemen kapalıdır. Çeşitli yasal ve dinî baskılara rağmen hayatın birçok dönemindeki bazı uygulamalar, açık veya gizli şekilde yapılmaya devam edilmektedir.
\end{abstract}

Bu durum doğumla ilgili inanç ve uygulamalarda da karşımıza çıkmaktadır. Doğum, bazı tıbbî uygulamalar dışında birçok dinî ve büyüsel uygulama ve işlemlerin yapıldığı bir geçiş dönemidir. Evlenmenin son aşaması olan "dinî nikâh"tan başlamak üzere, bebeğin kırklanmasına kadar geçen süre zarfında hem anne adayı hem de bebek için bazı uygulamalar yapılmaktadır. Gebe kalmak isteyen kadına yapılan dinî ve büyüsel işlemler ve kaçınmalar, doğumu kolaylaştıracağına inanılan uygulamalar, anne ve bebeğe zarar vereceği düşünülen kötü ruhlar ve bunlardan kaçınma yöntemleri ile nazardan kurtulma yöntemleri bunlardan birkaçıdır.

Makalede geçiş dönemlerinden olan doğumun Şambayadı Köyü'nde nasıl algılandığı; doğum öncesi, sırası ve sonrasına ait inanç ve uygulamaların neler olduğu ele alınmış; bu verilerin yorum ve işlevlerine yer verilmiştir. İncelemede kullandığımız veriler, Şambayadı Köyü'nde yaşayan ve mensubu olduğum Türkmenler arasında 2004'te yapılan derleme ve gözlemlerle elde edilmiştir.

Anahtar Kelimeler: Şambayadı Köyü, doğum, dinî ve büyüsel işlemler, al karısı, kırklama.

\section{Abstract}

Village of Şambayadı is a settlement in Çukurova, Adana. This village built by Şambayadı Yoruk/Turkmens as it understood by its name. Although these Turkmens passed to settled

\footnotetext{
* Bu inceleme, 25-27 Mart 2016'da Edirne'de düzenlenen "Halk Kültüründe Aile Uluslararası Sempozyumu"nda "Şambayadı Köyünde Doğum İle İlgili İnanç ve Uygulamalar Üzerine Bir İnceleme" adıyla sunulmuştur. Yayımlamadığımız bu bildiri, makaleye dönüştürülürken bazı kısımlarında düzeltme, çıkarma ve ilaveler yapılmıştır.

** Öğr. Gör. Dr., Ege Üniversitesi Türk Dünyası Araştırmaları Enstitüsü, e-posta: fazilozdamar@hotmail.com, ORCID: https://orcid.org/0000-0002-1729-0265.
} 
life, they kept and used their rituals and treatments between the time of birth and death with their oral cultures like proverbs, tales, folktales, etc. It can be said "These cultural factors are still alive because of Turkmen's isolated life against cultural impacts in the the region in question". People of Şambayadı village has not any relation with modern life except some modern traditions like "birthday celebration" and "woman's meeting day". Although there are some pressures from religious and government powers, some cultural factors in many phases of life lived in public or private.

This situation seems in religious rituals and treatments about birth. Birth can be described as some kind of passing process that includes lots of religious and magical layers except some medical treatments. After the religious wedding as last stage of marriage, there are some practices for mother and child until the child's 40th day like "religious and magical treatments and abstinences for woman who wants to be pregnant", "protecting them from evil spirits who can harm mother and child" and "protection both of them from evil eye".

This article includes "perception of the birth as known as passing process in Şambayad1 village", discusses about "rituals and treatments before birth, the moment of birth and after the birth", and thoughts and function of these rituals and treatments. Materials in this paper have been obtained in 2004 based on collecting and observation between Şambayadı Village and Turkmens I am a member of.

Keywords: Şambayadı Village, birth, religious and magical practice, al karısı (alp/nightmare), kırklama.

\section{Giriş}

Adana ili, Çukurova ilçesine bağlı (6.03.2008'e kadar Seyhan ilçesine bağlıydı.) ve şehir merkezine 15 km uzaklıkta bir yerleşim birimi olan Şambayadı Köyü, 2004 yılındaki Büyükşehir Belediyesi Kanunu'yla ${ }^{1}$ mahalle yapılmıştır. Ancak her ne kadar mahalle yapılmışsa da hem burada yaşayan halk hem de Adana ahalisi, burayı hâlâ köy olarak telakki etmektedir.

31 Aralık 2019 tarihli son TÜİK verilerine göre nüfusu 5210 olan$^{2}$ bu yerleşim biriminde ilköğretim okulu, elektrik, telefon, asfalt yol ve içme suyu ile kanalizasyon hizmetleri vardır ancak sağlık ocağı ve PTT şubesi yoktur. Köy halkı genellikle tarım, hayvancılık, nakliyecilik ve ticaretle (küçük çaplı da olsa) uğraşmaktadır. Köy halkının okuma yazma oranı, yaşlı nüfusta özellikle de kadınlarda ciddi oranda düşüktür.

Şambayadı Köyü'nde yaşayan Yörük-Türkmenlerin bir kısmı Alevi iken büyük çoğunluğu Sünni'dir. 1990'lı yıllardan sonra köye, Güneydoğu ve Doğu Anadolu bölgelerinden bir miktar Kürt kökenli grup da gelmiştir. Ancak bu grup, coğrafi olarak köyün dışında kalmış, resmî olmasa da kendi mahallelerini oluşturmuşlardır. Bunun yanı sıra yerleşim biriminin mahalle yapılmasının ardından köy arazisine TOKİ konutları ile bazı siteler yapılmıştır. Buralarda oturanlar da Şambayadı Türkmenleri değildir ve bunların köy ile kültürel bağları yoktur. Sadece resmî işlerde köye uğramaktadırlar. Bu sebeple incelemeye sadece Şambayadı Türkmenleri dâhil edilmiştir.

Şambayadı Türkmenleri, adından da anlaşılacağı üzere Oğuz Türklerinin Bayat boyundandır. Bu oymağın Yeni-İl ve Boz-Ulus'a mensup olduğu, 1613 tarihinde Anadolu'ya geldikleri ve Adana, Adıyaman ve Karaman'a yerleştirildikleri araştırmacılar tarafından belirtilmektedir (Aydın 1984: 71-72; Refik 1989: 215-216; Sümer 1999: 249-250).

\footnotetext{
1 Söz konusu köy, 5216 sayılı Büyükşehir Belediyesi Kanunu ile mahalle yapılmıştır. Karar, 23.07.2004 tarihinde Resmî Gazetede yayımlanmıştır.

2 https://biruni.tuik.gov.tr/medas/?kn=95\&locale=tr Bu nüfusun bir kısmını, TOKİ konutları ve köyün çevresinde bulunan sitelerde yaşayanlar oluşturmaktadır. Söz konusu köyün yaklaşık nüfusunun 2019 yılı verilerine göre 3000 civarında olduğu tahmin edilmektedir.

3 Alevi terimi, köyde yaşayan ve bu inanca mensup olan kişiler tarafından yapılan bir adlandırmadır. Sunni halk, bu grubu Alevi dışında Kızılbaş olarak da telakki etmektedir.
} 
Bu Türkmenler, söz konusu üç ilde hâlâ "Şambayadı" adıyla yerleşim birimlerinde yaşamaktadırlar. ${ }^{4}$ Bir diğer kaynakta da yukarıdaki bilgi doğrulanmaktadır: "Şambayadı, Karaman'da bir mahalle, Adana'da, Behisni, Afyon, Sivas'ta bir köydür. Bu köyler, vaktiyle Şam Araplarından kaçarak Anadolu'ya sığınan Bayat yürüklerindendir."5 (Yalman/Yalgın 2000: 56).

İnceleme konusunun dışına çıkmamak adına söz konusu Şambayadı Türkmenleri hakkındaki bu kısa bilginin yeterli olacağı kanısındayız. ${ }^{6}$

\section{İnceleme Yöntemi ve Doğum Kavramı}

Makalede; Adana ili, Çukurova ilçesi, Şambayadı Köyü'nde geçiş dönemlerinden biri olan doğumun nasıl algılandığı, doğum öncesine, esnasına ve sonrasına ait inanç ve uygulamaların neler olduğu ele alınıp bunların yorumlarına ve işlevlerine yer verilecektir. İncelemede kullanılan malzemeler, Şambayadı Köyü'nde yaşayan ve mensubu olduğumuz Türkmenler arasında 2004'te yapilan derleme ve gözlemlerle elde edilen verilerdir.

İncelemede, Sedat Veyis Örnek'in “Türk Halk Bilimi" (2000: 131-147) ve "Geleneksel Kültürümüzde Çocuk" (1979: 23-112) ile Orhan Acıpayamlı'nın “Türkiye'de Doğumla İlgili Âdet ve İnanmaların Etnolojik Etüdü" (1974: 13-96) adlı çalışmalarındaki tasnif temel alınacaktır. Derlemede, Metin Ekici'nin "Halk Bilgisi (Folklor) Derleme ve İnceleme Yöntemleri” adlı kitabındaki (2011: 159-163) ilgili bölümlerden faydalanılmıştır.

İnsanın dünyadaki yolculuğunun ya da insan hayatının ilk geçiş dönemi olan doğum, hem çekirdek hem de geniş aile açısından oldukça önemli bir dönemdir. Bu dönemde; kadının daha doğum öncesinde, hatta çocuk olma isteğinden başlayarak birtakım âdetlere uymaya, bu âdetlerin gerektirdiği işlemleri yerine getirmeye zorlandığ1 görülmektedir (Örnek 2000: 132). Bu dönem, annenin gebe kalma isteğinden başlayarak doğumdan sonraki kırklama işlemine kadar belli başlı inançlar çerçevesinde oluşmuş ve yüzlerce dinî ve büyüsel işlemin yapıldı̆̆ı bir sürece dönüşmüştür.

İnsan hayatındaki bu ilk geçiş dönemindeki inanç ve uygulamalar, incelemede "doğum öncesi, sırası ve sonrası" olmak üzere üç başlık altında incelenecektir. Bu başlıklar altında kısırlığı giderme yolları, aşerme, bebeğin cinsiyeti, gebe kadının kaçınmaları, bebeğin eşi/plasentası, al karısı ve kırk basması tasarımı ile bu sebeple yapılan kırklama işlemi ve son olarak geleneksel sağaltma yolları şeklinde kurgulanan alt başlıklardaki inanç ve pratikler ele alınacaktır.

\section{Doğum Öncesi}

\section{1. Kısırlığı Giderme ve Gebe Kalma}

Bebek sahibi olmak isteyip de gebe kalamayan kadın, bu isteğine ulaşmak için birtakım pratik ve işlemlere başvurur. Günümüzde doktora gittiği hâlde gebe kalamayan bir kadın ya da eşinin gebe kalmasını isteyen bir erkek, doktor denetimindeki tedavi süreci devam ederken bile birtakım dinî ve büyüsel işlemlere başvurarak bebek sahibi

\footnotetext{
4 Şambayadı Türkmenleri hakkında ayrıntılı bilgi için bk. (Sümer 1952: 373-398; Aydın 1984: 71-74).

5 Yalman/Yalgın'ın aynı eserinde sözlü kaynağa dayandırdığı; “Elgazidede Hacı Bekir Bey isminde biri, yedi yüz yıl önce Bă̆dat'tan Şam'a gelmiş ve bin çadırlık aşiretiyle Şam'dan Anadolu'ya girmiş, beğendiği yerde büyük saygı ile yerleşmiştir." (Yalman/Yalgın 2000: 127) bilgide de Şambayadı boyunun, Bağdat'tan Şam'a; oradan da Anadolu'ya göç ettiği anlaşılmaktadır.

6 İlgili köyün fiziki yapısı, tarihi, nüfusu vd. özellikleri hakkındaki temel bilgiler, yayımlanma süreci devam eden "Şambayadı Köyünde Bebeklik ve Çocukluk Dönemi İnanç ve Uygulamaları Üzerine Bir İnceleme" adlı makaleyle büyük oranda ortak bilgiler içermektedir.
} 
olmayı amaçlamaktadır. Şambayadı Köyü'nde bu dönemdeki bazı inançlar ve bu sebeple yapılan uygulamalar şunlardır:

Bebek sahibi olmak isteyenler, ocaklı kadınlara ${ }^{7}$ ya da halk hekimi kabul edilen bazı ebelere giderler. Bu kişiler, bebek sahibi olmak isteyen kadının göbeğini çekerler ${ }^{8}$ (KK 2; 3; 5; 8) ${ }^{9}$. Gidilen bu ocakların biri Şambayadı Köyü'nde Alevi Türkmenlerin ocağ1 olan Tulunoğulları Ocağı'dır. ${ }^{10}$ Burada ocaklı kadın, ateş yakar ve gebe kalmak isteyen kadını evin içindeki ocağın yanına yatırır. Daha sonra kadının beline kiriş adı verilen bir ip ile yağlık/yazma bağlanır ve kadının göbek kısmına "çekme" adı verilen masaj yapılır. Kadın, daha sonra bir süre ocağın yanında yatıp bebek sahibi olmak adına dua eder. Ocakta yapılan bir diğer işlem ise ocağa giden kadının göbeğine isıtılmış taşın koyulmasıdır (KK 2; 3). Kadın, bu işlem sonrasında ebe veya ocaklı kadına bir hediye verir ve "arlık"11 adı verilen demir parayı yere atar. Arlığın yere atılması şarttır ve böylece bu işlemin sağaltıcı olacağına inanılır (KK 2).

Gebe kalmak isteyenlerin gittikleri bir diğer mekân Ashâb-1 Kehf'tir.12 Buraya gidenler, dua etmenin dişında adak da adamaktadırlar (KK 2; 5; 8). Adak, "Sayrllıktan sağalma, çocuk sahibi olma, evlenme, zor bir durumdan kurtulma vb. amaçlara yönelik isteklerin yerine getirilmesi için yüce varliklara, ermişlere, tapınaklara, yatırlara, ziyaretlere adanan oruç, kurban, yiyecek, eşya vb." (Örnek 1973: 11) şeklinde tanımlanmaktadır. Şambayadı Köyü'nde birçok istek için adak adansa da inceleme konumuz olan doğumda köy halk1 genellikle çocuklarının, özellikle de erkek çocuklarının olması dileğiyle adak adarlar. Adak adanan birkaç mekân varsa da biz en çok ziyaret edilenlerden bahsetmekle yetineceğiz. Bunlardan ilki yukarıda adı verilen ve Tarsus'ta bulunan Ashâb-1 Kehf'te yapılır. Aile üyeleri ve hısımlarla beraber Ashâb-1 Kehf'e giden adak sahibi, burada bulunan mağaraya girerken ve camide namaz kılarken dua edip bebeği olması için dilek diler. Ardından da beraberlerinde getirilen hayvan (genelde küçükbaş) adak olarak kesilir. Dua ya da dilek dilenirken kabul olması durumunda belli başlı şeyler yapılacağı taahhüt edilir. Köy halkınca gerçekleşmesi istenen şey için ne kadar zor bir şey taahhüt edilirse dileğin o kadar hızlı gerçekleşeceğine inanılır. Örneğin erkek çocuk sahibi olmak isteyen bir kişi, oğlu olursa onun saçını yedi yıl kestirmeyeceğini ve her yıl Ashâb-1 Kehf'te adak kurbanı keseceğini adamış ve oğlu olduktan sonra bu sözünü tutmuştur. Bir diğeri de eriştiği dileği sonucunda aynı sebeple yedi yıl, art ardına Ashâb-1 Kehf'e gidip adak kurbanı kesmiştir. Tanık olduğumuz bu iki olay sonucunda iki aile de erkek çocuk

\footnotetext{
7 Halk hekimliğinde bir önceki kuşaktan el verme suretiyle aktarılan bilgileri kullanarak belirli bir şikâyeti veya hastalığı iyileştirdiğine inanılan aileye "ocak" adı verilmektedir (https://sozluk.gov.tr). Türk kültüründe "ocak" kültü hakkında bk. (Ekici ve Öger 2007: 1357-1367; İçli 2013: 95-101).

8 Göbek çekmek; ocaklı kabul edilen kadın veya geleneksel olarak ebelik yapan bir kadının, gebe kalmak isteyen kadının göbeğini ovarak yaptığı bir masajdır. Masaj öncesinde masaj yapılacak kadının bel ve göbek kısmının sıcak bir bezle sarılarak ısıtılması sağlanır. Ardından ocaklı kadın, çeşitli dua ve isteklerle kadının yumurtalık bölgesi ve göbek kısmına masaj yapar. Bu işlemin kadının gebe kalmasına yardımcı olacağına inanilir.

${ }^{9}$ Kaynak kişiler için “KK" kısaltması kullanılmıştır.

10 Şambayadı Köyü'nde Alevi mahallesinde bulunan, hem Alevi hem de Sünni grupların çeşitli dilekler için gittikleri bir ocaktır. Genellikle çocukları olmayan kadınlar giderler. Ayrıca bu ocağa vücuttaki yel, sızı vb. rahatsızlıkları gidermek için de gidilmektedir (KK 2; 5).

11 Kurban kestirmek, hastalıklara okuyup üflemek gibi inançlar karşılığında bu işi yapana verilen para (https://sozluk.gov.tr).

12 Kur'an'daki Ashâb-1 Kehf kıssasının geçtiği ve Tarsus'ta (Efes ve Afşin'de de Ashâb-1 Kehf olduğu kabul edilen mağaralar da vardır.) bulunduğu iddia edilen mağara (Ersöz 1991: 465-467). Şambayadı Köyü'nde bebek sahibi olmak isteyenler, oğulları askere gidenler ve hacca gidenler tarafından ziyaret edilen ve adak adanan yerlerden en önemlisidir. Genellikle sabah gidilip akşam dönülmekte ve adanan adaklar orada kesilmektedir (KK 2; 3; 5; 8; 11).
}

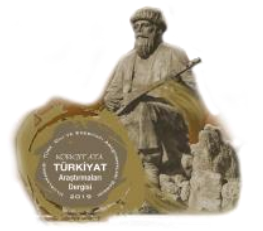

Korkut Ata Türkiyat Araştırmaları Dergisi

Uluslararası Türk Dili ve Edebiyatı Araştırmaları Dergisi

The Journal of International Turkish Language \& Literature Research

Sayı 5/ Ağustos 2021 
sahibi olunca bebeği olmayan birçok ailenin de aynı yerde, benzer adak yolunu uyguladıkları gözlemlenmiştir.

Dua ve adak için gidilen diğer yerler arasında Arıkl1 ${ }^{13}$ ve Sefil Dede ${ }^{14}$ türbeleri de bulunmaktadır. Bebek sahibi olmak isteyenler, bu türbelerde bulunan dilek ağaçlarına renkli bez parçası bağlamakta ya da bezden salıncak yaparak asmakta ve bu sayede bebek sahibi olmayı dilemektedirler (KK 2; 5; 8; 11).

Bu yatır ya da ziyaret yerlerinde veya ocaklı ailelerin evlerinde yapılan işlemlere, Türkiye'nin muhtelif bölgelerinde de rastlanmaktadır ve yatırlardaki "ermiss" ya da olağanüstü güçlere sahip olduğu düşünülen evliyalar ve bu ocaklı kişiler yoluyla, bu eksikliğin sağaltılacağına inanılır (Boratav 1984: 113-114; 123-124).

Bu konudaki bir diğer büyüsel işlem de "hac buğdayı" nın yenmesidir. Hacca gidenlere bir kese içerisinde verilen buğday, kutsal kabul edilen topraklarda dolaştırıldıktan sonra tekrar köye getirilir ve gebe kalmak isteyen kadın, Cuma sabah namazının ardından bu buğdayları yiyip zemzem suyu içer. Bu işlem vasıtasıyla da kadının gebe kalacağına inanılır (KK 1; 2).

Bebek sahibi olmak isteyen kadınların yaptığı bir diğer işlem de kadının gizli bir şekilde temiz bir toprağa "küçük abdestini yapması" ve bunun ardından ıslanan toprağın üzerine kıyafetiyle oturmasıdır. Böylece kötü ruhların idrarla toprağa geçeceğine ve kadının gebe kalacağına inanılır (KK 3).

Son örneğimiz ise düğün esnasında yapılan bir uygulamadır. Köyde yapılan düğünlerde, düğünün son günü -Pazar günü- misafirlere ikram edilen yemekler arasında ikisi dikkati çekmekte ve bu yemekler, her düğünde özellikle pişirilmektedir. Bunlardan ilki, bir çeşit mantı çorbası olan "Tatar aşı"dır. Düğünde bu çorbanın pişirilmemesi durumunda evlenen çiftlerin çocuklarının olmayacağına inanılır. (KK 3) Bir diğeri ise bulgurdan yapılan ve topalak adı verilen çorba çeşididir. Islak bulgurun kıyma ve çeşitli baharatlarla karıştırılıp yuvarlanmasıyla yapılan ve bir tencere yemek pişirmek için yüzlerce taneye ihtiyaç duyulan bu yemeğin düğünde pişirilmesinde bu çokluk etkili olmuş ve bu sayede "gelinin topalak gibi çocuklar doğuracağına" inanılmıştır. (KK 5)

Köyde yapılan kısırlı̆̆ı giderme yolları bağlamında yapılan bu uygulamalar, kutsal kabul edilen mekân ve kişilerden beklenen yardım ile kötü ruhlardan arınarak isteğe ulaşma şeklinde sınıflandırılabilir.

13 Arıklı Ziyareti: İçel ili, Tarsus ilçesi Arıklı köyündedir. Kapısında Şeyh Muhittin Semekandî olduğu yazılıdır. Tuğla binada namaz kılınacak ve yatacak yerler vardır. Buraya bebeği olmayan, hastalar ve evlenmek için eş isteyenler gelirler. Türbenin bulunduğu yerdeki ağaç diplerinden Cuma akşamları bir 1şık yükseldiği ve zamanla kaybolduğu; 1şıkların geldiği yerler kazılınca buralardan kemikler çıktığı ifade edilmektedir. Bakımı köy yönetimince yapılan türbeyi, yılda 3000-4000 kişi ziyaret etmektedir (Kalafat 1999: 421) Şambayadı Köyü'nde genellikle bebeği olmayan kadınların gittiği bir türbedir. Gidenler, türbedeki sandukanın üzerine yatar ve rüya görmeye niyet eder. Eğer kadın rüya görürse kadının bebeğinin olacağına inanilır. Bu türbeye ayrıca felçli olanlar da gitmektedirler (KK 8).

14 Şambayadı Köyü'nde bir Alevi türbesidir. Köyde yaşayan Sünniler de türbeye gitmektedirler. Bu türbeye genellikle bebek sahibi olmak isteyen kadınlar, evlenmek isteyen kızlar ve kocası askere giden kadınlar, dileklerinin kabulü için gitmektedirler (KK 11). Türbenin bahçesinde dilek ağacı olarak kullanılan bir ağaç vardır. Bu ağaca bebek sahibi olmak isteyenler, bezden bir salıncak yapıp içine bir taş koyarlar ve bunu ağaca bağlayıp sallarlar. Dileklerinin kabul olması için de adak adarlar. Dilekleri kabul olunca da adaklarını yerine getirirler (KK 2; 3; 8; 11). Bu türbe, günümüzde Adana Ehl-i Beyt İnanç Eğitim ve Kültür Vakfı adıyla cem evine dönüştürülmüştür.

Korkut Ata Türkiyat Araştırmaları Dergisi
Uluslararası Türk Dili ve Edebiyatı Araştırmaları Dergisi
The Journal of International Turkish Language \& Literature Research
Sayı 5/Ağustos 2021




\section{2. Yeme-İçme/Aşerme}

İster doğal yolla isterse yukarıdaki uygulamalar sonucunda olsun gebe kalan bir kadın, bazı yiyecekleri yemekten kaçındığı gibi, akrabası olan kişiler tarafından bazı yiyecekleri de yemeye zorlanabilir (KK $2 ; 3 ; 5 ; 10)$.

Bu yiyeceklerin hem anne adayı hem de bebeğin sağlığı ile ilgili olduğu söylense de bazen bebeğin cinsiyetinin belirleneceği düşüncesiyle de yapılabilir. Bu bağlamda gebe bir kadın, ekşili ve acılı yiyecekleri aşerirse doğacak bebeğin kız; tatlı yiyecekleri aşerirse bebeğin erkek doğacağına inanılır (KK 2; 3; 5; 8; 10;11).

\subsection{Gebelik}

Gebe kalan kadınların gebelikten başlayıp doğum yaptıktan sonra "kırkı çıkana (40. güne)" kadar "iki can taşıdıkları" na inanıldığı için ailenin temel geçim kaynağı olan mesleklere bağlı olarak, kadının zorlanacağı ya da güç gerektirecek işleri (hayvan bakımı, tarlaya gitme vd.) yapmalarına izin verilmez. Bu kadınlar, bazı kaynak kişilere göre "hasta insan" kabul edilmekte ve doğumdan sonra kırkı çıkacağı güne kadar tedavi edilmesi gerektiğine inanılmaktadır (KK 2; 3; 8; 11).

Şambayadı Köyü'nde "yüklü" adıyla adlandırılan gebe kadınlar, her ne kadar mutlu bir olayı yaşatacak kişiler olsalar da gebeliğin getirdiği baş dönmesi, mide bulantısı, kusma, karın büyümesi gibi sonuçlardan dolayı ailesinden ve komşularından utanabilirler (KK 8). Gebe kadınların özellikle de kayınbabasının ya da ailesindeki yaşlı erkeklerin yanına gitmedikleri, onlarla konuşmaktan mümkün olduğunca kaçındıkları gözlemlenmiştir.

\section{4. Bebeğin Cinsiyeti}

Bebek, toplumda soyun devamı olarak düşünüldüğü için bebeğin cinsiyeti oldukça önemlidir. Köy halkınca soyun devamının erkekler tarafından sağlanacağ1 düşünüldüğünden anne ve baba, bir çocuğunun erkek olmasını ister. Bu sebeple de doğacak çocuklardan birisinin erkek olması için birtakım dinî ve büyüsel işlemlere başvurulur (KK 2; 3; 5; 8; 11). Bunlara baktığımızda şu pratikleri görmekteyiz:

Doğacak bebeğin erkek olması için başvurulan en yaygın işlemlerden biri gebe kadına tatlı yiyeceklerin yedirilmesidir (KK 2; 3; 5; 10; 11). Yukarıda da ifade edildiğine gibi köy halkınca ekşi yiyen kadının kız, tatlı yiyenin ise erkek bebek doğuracağına inanılır. Bu inancın, yemekler arasında tatlının ekşiye göre daha fazla tercih edilmesi sebebiyle erkek çocuğun $\mathrm{klz}$ çocuklara üstün olduğunun düşünülmesinden kaynaklanması etkili olmuştur (Örnek 1966: 59).

Bir diğer işlem ise dinî bir uygulamadır. Bu işlemde erkek bebek doğurması istenen kadın, gebelikten önce hocaya/imama götürülür ve hoca, bebeğin erkek olması için bir takım dualar eder. Bu uygulama, genellikle birkaç kız doğuran kadınlara ailesindeki yaşı büyük kadınlar tarafından yaptırılmaktadır (KK 8).

Birkaç kız çocuğu olan aile, bir sonraki bebeğinin erkek olması için birtakım büyüsel işlemlere de başvurabilir. Bunlardan en yaygın olanı, en son doğan kızın adının "Şenel" koyulmasıdır (KK 2; 5; 8; 10; 11). Bu durumu kaynak kişilerimiz şu şekilde açıllamaktadırlar: "Art arda kızı olanlar, son kızın adını Şenel koyarlar. Arkası şenelsin, şenlensin diye. Kamber A ̆ğa'nın beş kızı olunca son kızının adını Şenel koymuş. Sonraki çocuğu ise erkek (Menderes) olmuş. Ondan sonra oğlu olmayan diğer köylüler de oğlunun olması için kızlarının birinin adını Şenel koymaya başladılar. Turgut dayın da Sermin teyzen de koydu, onların da oğulları oldu." (KK 5; 8). 
Erkek çocuğunun olması istenen kadınlara yaptırılan bir diğer büyüsel işlem ise dügüun esnasında görülmektedir. Düğünde gelin, yeni evine girmeden önce kucağına erkek bebek verilir. Bu sayede kadının oğlunun olacağına inanılır (KK 2; 3; 4; 6; 8; 11). Bu durum, temas büyüsü şeklinde açıklanabilir. Erkek bir bebekle temasa geçen kadın, gelecekte bu sayede erkek çocuk dünyaya getirecektir (Örnek 1966: 36-37).

\section{5. Gebe Kadının Kaçınmaları/Uygulamaları}

Hamilelik sürecinde nazar ve kötü ruhlardan korunmak için yukarıdaki pratikleri uygulayan gebe kadın, bazı uygulamaları da yapmaktan kaçınmaktadır. Bunlardan bazıları şunlardır:

Hamile kadın, gebelik süresince güzel nesne ve insanlara bakarsa karnındaki bebeğin güzel olacağına inanır (KK 2; 5; 8). Bir kaynak kişi, bu uygulamayı; "Yüklü avrat, "keleş"e [güzele] bakarsa bebek keleş, çirkin ve sakata bakarsa çirkin ve sakat olur." şeklinde açılamıştır (KK 5). Gebe kadının kaçınmasına bir örnek ise kadının, gebeliği süresince ve doğumdan kırk gün sonrasına kadar mezarlığa gidememesi ve cenazeye katılamamasıdır (KK 2).

Bunların dışında köy halkınca erkek bebeklerin dayıya, kız bebeklerin ise halaya benzeyeceğine inanılır (KK 8; 12). Ayrıca köy halkı arasında "bene" sahip olmak bir güzellik belirtisidir. Bu sebeple de doğacak bebeğin "bene" sahip olması için gebe kadına siyah dut yedirilir. Böylece bebeğin benli doğacağına inanılır (KK 2; 13).

\section{Doğum Sirası}

Kadınların doğum sırasındaki güçlüklerini gidermek ve onların doğumunu kolaylaştırmak için de birtakım uygulamalara başvurulur. Gebe kadının doğumu yaklaşınca hem kadın hem de ailesi, birtakım hazırlıklar yapar. Yıllardır doğum yaptıran ve bu sayede deneyim kazanan bazı kadınlara bilindiği üzere "ebe" adı verilmektedir. Geçmiş dönemlerde doğumu yaptıran bu kadınlara da yağlık/yazma, kına vb. hediyeler verilirmiş (KK 2; 14). Eskiden sadece ebeler tarafından yaptırılan doğum, günümüzde doğum evlerinde ve hastanelerde yaptırılmaktadır.

Eskiden doğum sancısı olan kadınlara bir oklava verilir ve kadın, bu oklava yardımıyla dolaştırılır ve uzun bir süre yürütülürmüş ve bu işlem sayesinde doğumun kolaylaşacağına inanılırmış (KK 5; 8).

Doğumu kolaylaştıracağı düşünülen bir diğer işlem ise doğumu yaklaşan kadınların, doğum sırasında Allah'ın yardımını kazanmak için namazlığın/seccadenin üzerinde yedi kez yuvarlanmasıdır (KK 2;8).

Eskiden evde yapılan doğumlarda kullanılan malzemeler ise şunlarmış; bebeğin göbek kordonunu bağlamak ve kesmek için ip-makas ile sıcak su, tuz, belek, leğen ile anne ve bebek için kıyafetler (KK 2; 5; 8).

Eskiden bebek doğar doğmaz tüm vücudu tuzlanir ve üç gün boyunca yıkanmazmış. (KK 8) Bu durum, Şambayadı Köyü halkında, geveze ve boş konuşan kişilere söylenen; "Sen ne kadar tuzsuzsun? Anan seni hiç tuzlamadı mı?" gibi deyimlerde de görülmektedir (KK 8; 9). Ancak günümüzde doğum, doğumevlerinde ve hastanelerde yaptırıldığından tuzlama işlemi ilk gün yapılmasa da bazı ailelerin, bu işlemi bebeğin hastaneden eve getirilmesinin ardından yaptıklarına şahit olduk. İlk yıkamadan başka bebeğin "yarı kırkında" ve "tam kırkında" mutlaka "kırklanarak" yıkanması gerekmektedir (KK 8). Kırklama işlemi, ileriki kısımda ele alınacaktır. 
Doğan bebek, yıkandıktan sonra annesinin kucağına verilir. Anne, bebeğini emzirir, böylece bebeğin annesine alışması sağlanmış olur.

\section{Doğum Sonrası}

Doğum sonrasında doğumun duyurulmasından başlayarak hem bebeği hem de anneyi koruyacağına inanılan bazı sağaltıcı işlemler de vardır.

Bebek doğunca bu "muştulu" haber, aile bireylerine duyurulur. Halk arasında "kulak almak" denen bu olayda haberi veren kişiye "muştuluk" adı verilen bir hediye verilir. Genellikle bu durum, ilk bebekte veya erkek çocuklarda hediyenin maddi değeri $\operatorname{artar}(\mathrm{KK} 2 ; 5 ; 8)$.

Doğum sırasında kötü ruhları uzaklaştırmak ve doğum sonrasında hem bebeğe hem anneye hem de aileye gelebilecek nazarı bertaraf etmek için üzerlik tüttürülür (Emeksiz 2012: 233). Üzerlik, tüttürme dışında evin herhangi bir yerine de asılabilir. Sadece doğum sırası ve sonrasında değil, ölüm dışındaki tüm geçiş törenlerinde ve aileye alınan herhangi bir eşyada da tüttürülen üzerlik; gün içinde bazen üç, bazen de yedi kez tekrarlanabilir (KK 2; 5).

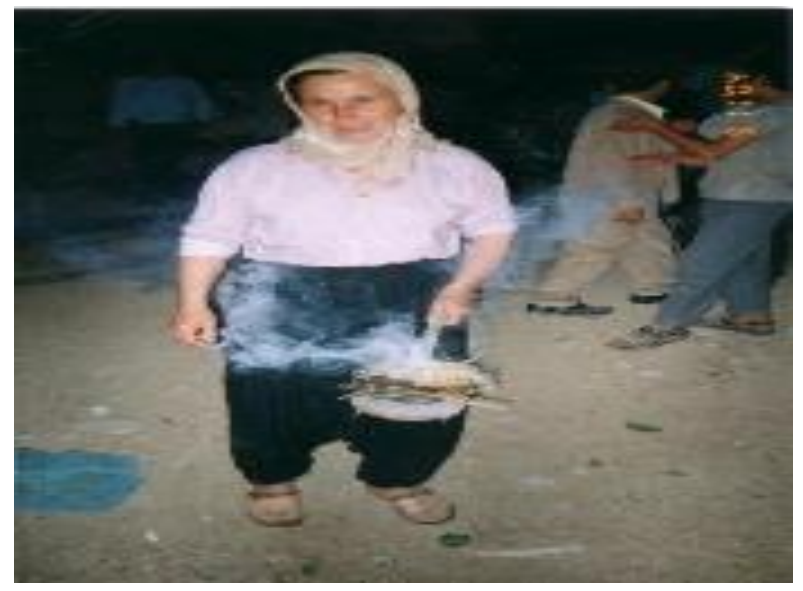

Fotoğraf 1: Üzerlik tüttüren bir kadın.

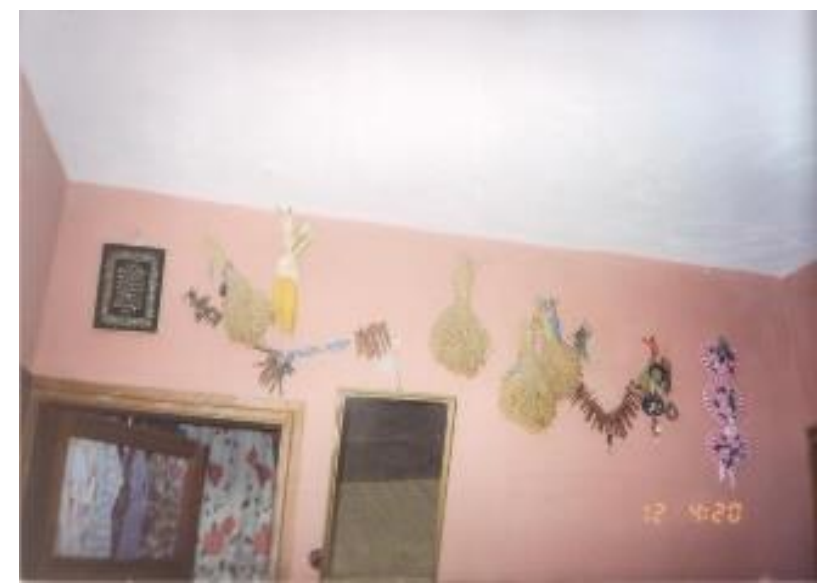

Fotoğraf 2: Evde asılı nazarlıklardan bazıları: Nazar boncuğu, karaçalı, üzerlik, darı ile diğer süs ve nazar eşyaları.

Eskiden bebek doğunca "bebeğin rızkının bol olması" için üç gün boyunca buğday eleğinde yatırılırmış (KK 8). Benzetme yoluyla yapılan bu işlem, günümüzde düğünde buğday, arpa ve mısır taneleri ile yapılmaktadır. Düğün esnasında gelin ve damada saçı olarak atılan bu tahıllar ile yeni evlenen çiftin evlerinin bereketli olacağına inanılmaktadır. 
Lohusa kadının sütünün bol olması için anneye genellikle şekerli yiyecek ve içecekler verilir. Bunlar arasında yağlı ballı,15 palıza, ${ }^{16}$ helva, hoşaf vb. tatlılar ile meyve suları sayılabilir (KK 2; 5; 13). Anne sütünün bol olması için yapılan bu pratik dişında bir diğer uygulama da şişin ucuna asılmış bir soğanın bebeğin bulunduğu oda kapisına asılmasıdır (KK 2; 4; 8). Bu uygulama, ilgili kısımda detaylandırılacaktır.

Doğumun ardından bebeğin sarılık ${ }^{17}$ olmaması ya da sarılıksa hızlıca iyileşmesi için bebeğin yüzüne kırk gün boyunca sarı yağlık/yazma, kırk günden sonra ise kırmızı yağlık örtülür (KK 2; 3; 8). Köy halkınca yüzü ya da benzi sararmış bebeklerin sarılık olduğuna inanılır. Bu tür bebeklerin yüzüne -günümüzde doktor tedavisi altındayken bile- mutlaka sarı renkli yazma örtülür.

\section{1. Bebeğin Göbeği ve Eşi/Plasentası}

İster evde isterse doğumevi ya da hastanede yapılsın doğumun hemen ardından "Hayırlı olsun." denilerek kesilen bebeğin göbeğinde kalan parça, birkaç gün sonra düşünce bu parçacık, bazen cami avlusuna bazen okul veya hastane bahçesine bazen de yaşayacağ1 evin bahçesine gömülmektedir. Genel olarak bu mekânlar, bu bebeğin inançlı olması, evine bağlı kalması ya da gelecekteki mesleğinin belirlenmesi sebebiyle seçilmektedir (KK 2; 8; 11). Ebeveynlerin yaptığı bu işlemlerin birinde bebeğin gelecekte yapacağı mesleğin belirlenmesi düşüncesi vardır. Günümüzde "devlet memuru" olarak adlandırılan mesleklerin ön planda olduğu bu seçimde; geçimini tarım, hayvancilık, nakliyecilik ve küçük çapta yapılan ticaretle geçiren, genel olarak sağlık ve emeklilik sigortası dahi yatıramayan ve ekonomik sorunlar yaşayan ebeveynlerin, bebeklerinin de kendileri gibi ekonomik sorunlar yaşamaması ve öğretmen veya doktor gibi garanti bir ücret alarak çalışmasının istenmesi etkili olmaktadır. Çocukla belli bir süreden beri bitişik olan eşin, bebekten ayrıldıktan sonra bile bu bağlantıyı sürdüreceği, temas yoluyla parçanın başına gelenin ait olduğu bütünün başına da geleceği inancı, bu isteğin esasını teşkil eder. Temenni ve istekle ilgili olan bu uygulamalar, bünyeleri bakımından içten dışa, yani çocuktan teması arzulanan dış etkene doğru işlemektedir (Örnek 1966: 72).

Eskiden evde yapılan doğumlarda, belirli bir süre sonunda "eş"i düşmeyen kadın, dibeğe bağlanır, bir "sahan"la18 kadının karnına bastırılırmış; böylece kadının eşinin düşmesinin kolaylaşacağına inanılırmış (KK 8). Yine eski dönemlerde kadının eşinin düşürülmesinde başvurulan diğer işlemler şunlardır: "Susam" kaynatılır ve onun buharı, kadının eşine tüttürülürmüş (KK 8). Temiz kum, sacda kavrularak isıtılır ve kadın bu kumun üzerine bir süre yatırılırmış. Bunlarla da kadının eşinin düşmesinin kolaylaşacağına inanılırmış (KK 2; 8). Bu işlemlerde, köy halkının herhangi bir sağlık kuruluşuna erişememesi sebebiyle gelenekleşmiş bazı halk hekimliği tedavilerini uyguladıkları görülmektedir.

\section{2. Al Karısı Tasarımı}

Türkiye'nin muhtelif bölgelerinde al, alanası, alkızı, alkarı, albası ve albıs adlarıyla; diğer Türk boylarında ise alvastı (Özbekistan, Kazakistan, Başkurtistan, Tıva, Altay, Kırım, Kazan ve Sibirya Türkleri), albarstı (Türkmenistan), albash (Karakalpak ve Nogay Türkleri), hal henesi (Azerbaycan Türkleri), albaslı katın (Kumuk Türkleri), al apar (Kerkük ve Türkmenler), almastı (Karaçay ve Malkar Türkleri), kayış ayak (Dobruca Türkleri), taun ve rusali (Gagavuz Türkleri) adlarıyla anılan ve kötü ruhlardan sayılan alkarısı; Türk inanç

15 Yufkanın yă̆ ve bal (bazen şeker) ile karıştırılması ile oluşan bir çeşit tatlı.

16 Nişasta, su ve şekerle yapılan bir çeşit tatlı.

17 Derinin, dokuların ve organizmadaki sıvıların sarı bir renk almasıyla beliren hastalık, hepatit.

18 Derinliği az olan kap (https:/ / sozluk.gov.tr). 
sisteminde cin, peri, dev veya şeytan şeklinde tasavvur edilir. Bir çeşit hummanın tesiriyle ortaya çıkan ve genellikle ahır, samanlık, virane yerler, nehir kenarları, çeşme ve kaynak başlarında bulunduğu düşünülen alkarısının; anne ve bebeğine musallat olduğuna ve onların korkmasına, hasta olmasına hatta ölmesine neden olduğuna inanılır (Küçük 1989: 469; Beydilli 2004: 34; Yeşil 2014a: 99; Şimşek 2017: 100). Tüfek/silah sesinden, bazı ocaklıkişilerden, demirden ve kırmızı renkten korktuğuna inanılan alkarısı, genellikle kadın şeklinde tasavvur edilen kötü ruhlardan biridir ${ }^{19}$ (İnan 1998: 259-267; Sarpkaya $2021 ; 239)$.

Şambayadı Köyü'nde "alkarısı veya al" adıyla geçen bu ruhun, hem lohusa kadınlara hem de bebeklere sataştığına, onların üzerine bastığına ve al basan bebek ile annenin ağzından ve burnundan kan geldiğine, damağının/dişlerinin kilitlendiğine bu sebeple de ölebileceklerine inanılır (KK 2; 5; 8; 11). Bundan kaçınmak için köy halkı, aşağıda belirtilen dinî ve büyüsel bazı uygulamalara başvurmaktadır:

Öncelikle "kırklı" kadın ve bebek, asla yalnız birakılmaz. Bunların yanında mutlaka bir kişi -tercihen erkek- bulundurulur (KK 2; 5; 8; 10;11).

Bebeğin yatağının yanına ayna, ekmek parçası, Kur'an-1 Kerim konur; bebeğin yastığına çuvaldız ya da iğne, annenin kıyafetlerine ise çengelli iğne iliştirilir (KK 2; 5;8). Ayrıca bebeğin yattığı yere makas ve süpürgenin de koyulduğunu/asıldığını gözlemledik. Bunlardan ayna "aydınlık olsun" diye, çuvaldız ise al karısının iğneli nesnelerin bulunduğu yere gelemeyeceğinin düşünülmesinden dolayı asılmaktadır (KK 5; 8).

Köyde al karısının gelemediğine ya da korktuğuna inanılan bazı "ocaklı" kişiler vardır. Bu kişilerin elbiselerinden alınan bir parça, lohusa kadının ve bebeğin elbisesine iliştirilir. Böylece al karısının, bu kişilere gelemeyeceğine inanılır (KK 2; 8). Bir kaynak kişimiz, bazı kişilerin çengelli iğne batırarak alkarısını yakaladıklarına dair çeşitli memoratlar anlatmıştır. Anlatı; alkarısını yakalayan bu kişinin, alkarısının kendisini serbest bırakması için yalvarması sonucunda onun ailesinden bir kişiye ya da onun kıyafetlerini taşıyan bir kimseye zarar vermeyeceğine dair yemin ettirdikten sonra alkarısını serbest bıraktığı üzerine kuruludur (KK 2). Alkarısının bazı kişiler tarafından hapsedildiğine dair bazı anlatılar, hem Türkiye'de hem de Türk Dünyası'nın çeşitli bölgelerinde tespit edilmiştir (Beydilli 2004: 34-35; Yeşil 2014b: 121-122; Şimşek 2017: 99115).

\section{3. Kırk Basması Tasarımı}

Bebeğin doğumundan kırk güne kadar geçen süre zarfında hem bebek hem de anne "kırklı" olarak kabul edilir. Dolayısıyla da bu kişilere "kırk basabileceği" ve onlara zarar vereceğine inanılır. Kırk basan bebek ve annenin fenalaşacağına ve hasta olacağına inanılır (KK 2; 3; 5; 8; 11). Bunların dışında evlenen çiftler ve sünnet olan çocuk da kırklı sayılmakta ve doğumdaki uygulamaların onlara da yapıldığı görülmektedir (KK 8).

Şambayadı Köyü'nde anne ve bebeğe kırk basmaması için de dinî ve büyüsel bazı uygulamalar yapılmaktadır. Bunlardan en sık yapılanı, anne ve bebeğin kırk gün boyunca mecbur kalmadıkça evden dışarı çıkmaması ve yanında bir kişinin -tercihen erkekbulundurulmasıdır (KK 2; 5; 8; 10; 11). Bu durumun sebebini bir kaynak kişimiz; “Doğum yapan kadının mezarı kırk gün açık olurmuş, yani doğum yapan kadına 'yarı ölü' derler. O yüzden de lohusa kadını yalnız bırakmazlar." şeklinde açıklamıştır (KK 5).

19 Al karısı hakkında daha fazla bilgi için bk. (Acıpayamlı 1974: 75-85; İnan 1962: 2826; İnan 1986: 171; İnan 1998: 259-267; Küçük 1989: 469).

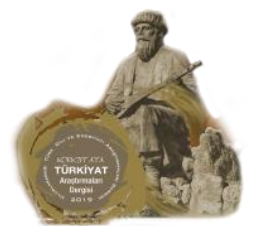

Korkut Ata Türkiyat Araştırmaları Dergis

Uluslararası Türk Dili ve Edebiyatı Araştırmaları Dergisi

The Journal of International Turkish Language \& Literature Research

Sayı 5/ Ağustos 2021 
Köyde evden dışarı çıkması mümkün olduğunca kısıtlı tutulan kırklı kadın, dışarı çıkmak zorunda kalırsa da bir diğer "kırklı" kadınla karşılaşmamaya özen gösterir. Bunların karşılaştığı durumlarda ise bu kadınlar, kıyafetlerindeki taşımak zorunda oldukları çengelli iğneleri değiştirirler. Böylece kırk basmasının önüne geçeceklerine inanırlar (KK 2; 7; 5; 8).

"Kırk basmaması" için yapılan bir diğer uygulama da kırklı bebeğin davulun üzerine yatırılmasıdır. Köye davul getirildiğinde (düğün, sünnet, asker uğurlama vb. kutlamalarda) köydeki kırklı bebekler, davulun üzerine konur (KK 2; 3; 4; 5; 7; 8; 11). Bu uygulama, davulun bebeklerde kırk basmasını engellediği inancından kaynaklanmaktadır (KK $2 ; 8)$.

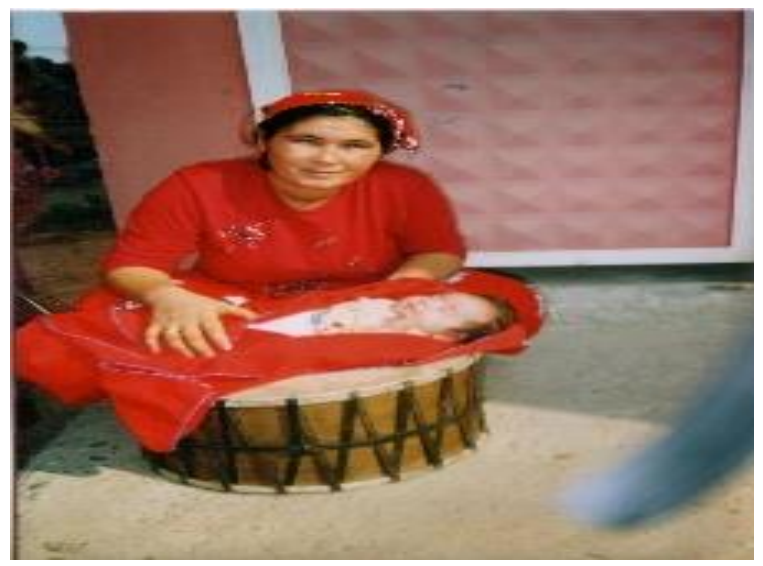

Fotoğraf 3: Yeni doğmuş bebeğin kırk basmaması için davulun üzerine yatırılması.

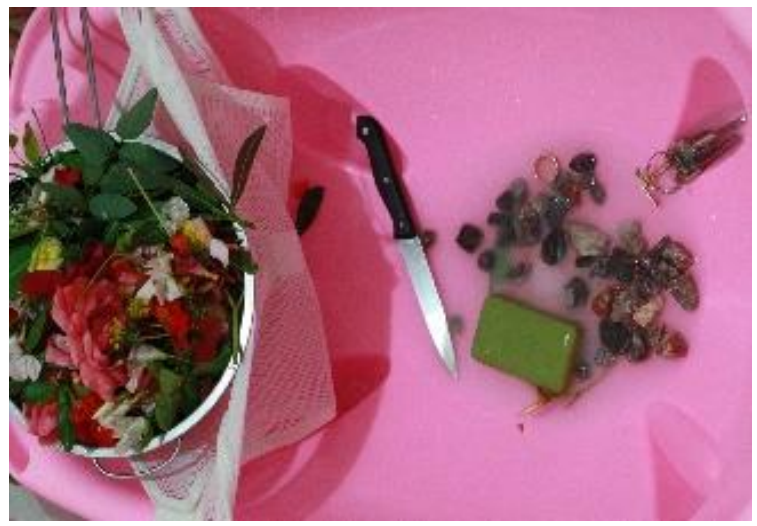

Fotoğraf 4: Kırklama işleminde kullanılan araç gereçler ile çiçekler.

Şamanizm'de şamanın öte dünyaya yolculuğunda bir araç olarak tasavvur edilen davul, İslam öncesi Türk inanç sisteminde şaman/kamın koruyucu ruhlardan izin aldıktan sonra yaptırabileceği ve dinî ayinlerde sadece kendisinin kullanabileceği bir araçtır (İnan 1986: 94; Drury 1996: 75). Bu ayinlerin çoğunda davul, kötü ruhların uzaklaştırılması amacıyla kullanılır. Günümüzde Anadolu'nun muhtelif bölgelerinde görüldüğü üzere Altay Türklerinde de ay ve güneş tutulmasında gürültü çıkarıp davul çalma, bu kötü ruhun uzaklaştırılması amacıyla yapılmaktadır (Gömeç 2003: 88). Bu bağlamda Şambayadı Köyü'nde bebeğe veya lohusa kadına zarar vereceğine inanılan kötü ruhların uzaklaştırılmasında davulun bu özelliği kullanılmaktadır.

\section{4. Kurklama İşlemi}

Evrensel olarak arınmada kullanılan ögelerin başında su, ateş ve toprak gelmektedir. Abdest ve kırklama su ile, teyemmüm toprak ile, ateşten atlama ve dağlama 
ise ateşle yapılan arınmalara verilebilecek bazı örneklerdir (Kasapoğlu Akyol 2020: 695696). Bunlardan suyla arınma ve yıkanma ritüelinin amacı, yaratılışın meydana geldiği zamanı canlandırmaktır ve dünyanın ya da "yeni insanın" doğumunun simgesel tekrarlarıdır. Bu bağlamda su, hem canlandırır hem de arındırır (Eliade 2000: 217). Ayrıca su, birçok ritüelde hastalığı yıkayıp atmakta kullanılan ve şifa veren bir öge durumundadır. Bu sebeple birçok kültürde hastalıktan ve günahlardan "su vasitasıyla arınma"nın çeşitli uygulamaları görülmektedir. Suyla arınmanın hem bedensel hem de ruhsal boyutu vardır. Türkiye'de bu arınmanın mekânı genel olarak hamamlardır. Doğumda kırk hamamı ya da lohusa hamamı, dügünde gelin/güvey hamamı, ölüme ise yas hamamı örneklerinde görüldüğ̈ü üzere bu arınmaya insan hayatının bütün geçiş dönemlerinde karşılaşırız (Kasapoğlu Akyol 2020: 697).

Şambayadı Köyü'nde kırsal yaşamın sürdürülmesi sebebiyle hamam kültürü gelişmediği için bu arınma, "kırklama" adı verilen ve evlerde yapılan bir işlemle sağlanır. Kırk bastığı düşünülen anne ve bebeğe yapılan "kırklama" işlemi, "yarı kırk" ve "tam kırk" olmak üzere iki defa yapılmaktadır.

Köyde bebeklerde kırklama işlemi şu şekilde uygulanmaktadır: bebeğin "yarı kırkı" çıktığında yani doğumunun yirminci gününde bir leğenin içine bir altın (genellikle yüzük), yirmi çeşit çiçek ya da ağaç yaprağı, yedi kuyudan alınmış su, anahtar, tarak, demir (genellikle demir para), sabun, yirmi adet denizden getirilmiş (ya da bir oluğun altından toplanmış KK 5) küçük taş konur ve ilk olarak bunların üzerine yirmi kaşık su dökülür. Daha sonra da bebek, hazırlanan bu suyla yıkanır. Bebeğe tas ile son kez su dökülürken "Kırk, kırk, kırk. Arlı̆̆ın, kırlığın, hastalı̆̆ın, kırklığın bu suyla gitsin." denilerek dua edilir. Dökülen son sudan sonra ise bebeğin önce elleri, sonra ayakları, en son da baş1 leğen içerisindeki suya batırılır ve boyunun uzun olması için bebek, önce başından sonra da ayaklarından tutulup sallanır. "Tam kırkı"nda ise aynı gereçler kullanılırken leğene koyulan taş, kaşıkla alınan su ve çiçek-yaprak sayısı kırka çıkarılır (KK 2; 3; 5; 8; 11). Kırklamadan artan sudan bebeğin salıncağına serpildiğini de gözlemledik.

Eskiden kırklama işleminden sonra bebeğin salıncağına ya da yattığı yatağa üç tane eşek pisliği, üç tane de küçük taş konurmuş. Kaynak kişimiz bunu; "Bebek kırklandıktan sonra eşek gibi uyusun, taş gibi de să̆lam olsun diye bunu yapardık." ş̧eklinde açıklamıştır (KK 2).

Kırkı çıkmamış bebeklerin üzerinden atlanarak geçilmez ve bebek insanın bel hizasının üzerinde taşınır. Hatta bazı kaynak kişilerimiz bebeğin elbiselerinin üzerinden dahi atlanmayacağına, atlanıldığı durumlarda bebeğin hasta olacağına inanıldığını söylemişlerdir (KK 3; 11).

Yukarıda da belirtildiği gibi kırklama işlemi, sadece kırklı kadın ve bebeklere yapılmaz. Bunun dişında sık sık hasta olan kişilere, kırklı olmayan zayıf ve cılız olan bebeklere de kırklama işlemi yapılmaktadır (KK 3; 5; 7; 11). Ayrıca evlenememiş (halk arasında "evde kalmış") kızlara da nazar değdiği düşüncesiyle bu işlemin yapıldığ1 görülmektedir (KK 5).

Doğumdan hemen sonra anneye ve birkaç ay sonra bazı yiyecekleri yemeye başlayan bebeğe belli bir süre (bazen bebeğin 1. bazense 2. yaşına kadar) çocukta sağlık açısından negatif etki bıraktığı düşüncesiyle bazı yiyecekler yedirilmez. Eğer anne ya da bebek, bu yemeklerden yerse bebeğin hasta olacağına inanılır. Bu duruma halk arasında "yemek değmesi ya da dokunması" adı verilmektedir (KK 2; 3; 5; 11). Bu, annenin yediği/içtiği bazı baharatlı ve asitli yiyecek/içeceklerin içinde bulunan bazı protein ve kimyasalları, süt yoluyla alan bebekteki alerjik reaksiyon ve karın ağrısıdır. Ayrıca bu 
durumdaki (yemek değdiği düşünülen) bebeklerin, eskiden üç kez Cuma günleri sabah ezanı okunmadan ciğer suyuyla kırklandığı söylenmektedir (KK 2; 3; 5).

\section{Geleneksel Sağaltma Uygulama ve İşlemleri}

Bir kadının sağlıklı bir yolla gebe kalması, bebeğinin sağlıklı bir şekilde gelişmesi ve doğması ya da bebekte doğuştan ve sonradan ortaya çıkabilecek bedensel, zihinsel ve ruhsal özürlerin giderilmesi, ayrıca çocuğu nazardan ve büyüsel içerikli zararlı dış etkilerden korumak için bir takım geleneksel sağaltma pratik ve işlemlerine başvurulmaktadır. Bu sağaltmalar doğum öncesinde kadına, sonrasında ise bebeklere uygulanmaktadır (Örnek 2000: 164). Şambayadı Köyü'nde hem anne adayına ya da anneye hem de bebeklere yapılan sağaltma işlemleri şunlardır:

Birkaç bebeği ölü doğan ya da doğumdan hemen sonra ölen kişiler, doğan bir sonraki bebeklerinin yaşaması için birtakım dinî ve büyüsel işlemlere başvururlar. Bu işlemler genel olarak anne adayı olan kadına yapılmaktadır. Bu kadınlar köyde ebe olarak kabul edilen ya da ocaklı kadına götürülür. Bu kadın, anne adayının göbeğini çeker (KK 2; 3 ; 5). Bu sebeple yapılan bir diğer uygulama da kadının "hocaya/imama" götürülüp bir çeşit muska olan "hamaylı" yazdırmaktır (KK 2; 5; 8).

Bir önceki bebeği ölen ailenin yaptığ bebeğin adını; "Yaşar, Yaşariye, Durdu, Duran, Durmuş, Dursun, Kalsın" koymaktır (KK 2; 5). Aynı uygulamaya Anadolu'nun çeşitli bölgelerinde ad olarak konulan Durali, Durbaba, Duran Satılmış, Ökkaş/Ökkeş, Taştan isimlerinde de raastlanır (Örnek 1966: 67; Acıpayamlı 1992: 8-9). Bebek doğar doğmaz hocaya gidilip "hamaylı" alınıp çocuğun elbisesine asılması ve adak adanması da bu bağlamda yapılan diğer işlemlerdir (KK 2; 5). Eskiden bebeğin ölmemesi için bebeğin ilk kakası bir beze sarılarak kırk gün boyunca bir odada saklanırmış. Bu sayede bebeğin ölmeyeceğine inanılırmış (KK 3).

Bir önceki bebekleri ölen ailelerin sonraki bebeklerinin ölmemesi için yaptığ bir diğer işlem de son bebeğinin saçını yedi yıl kestirmemeyi taahhüt edip her yıl adak kurbanı keseceğini adamaktır. Böylece doğacak bebeklerinin yaşatılacağına inanılır. Yedi yılın sonunda bebek ölmezse yeni bir adak kurbanı ile birlikte çocuğun saçı da kesilir (KK $2 ; 8 ; 13)$. Bu örneği incelemenin "doğum öncesi" kısmında detaylandırmıştık.

Bebeği hastalıklardan korumak için yapılan işlemlerden biri de bebeğin yattığ1 odanın kapısına demir bir şişe geçirilmiş soğan asılmasıdır. Bu işlemde; bir soğan demir şişe geçirilir, demirin en üst kısmına da kırmızı bir bez bağlanır. Daha sonra da bu, bebeğin bulunduğu odanın kapısına asılır (KK 2; 4;8). Burada asılan soğan, lohusa kadının sütünün bol olması; kırmızı bez, çocuğun büyüyüp evlenecek yaşa gelmesi ve dügününün (Şambayadı Köyü'nde düğün, damat evine bayrak asılması ile başlar.) olması; demirin ise bebeğin güçlü olması için yapıldığı söylenmektedir (KK 2).

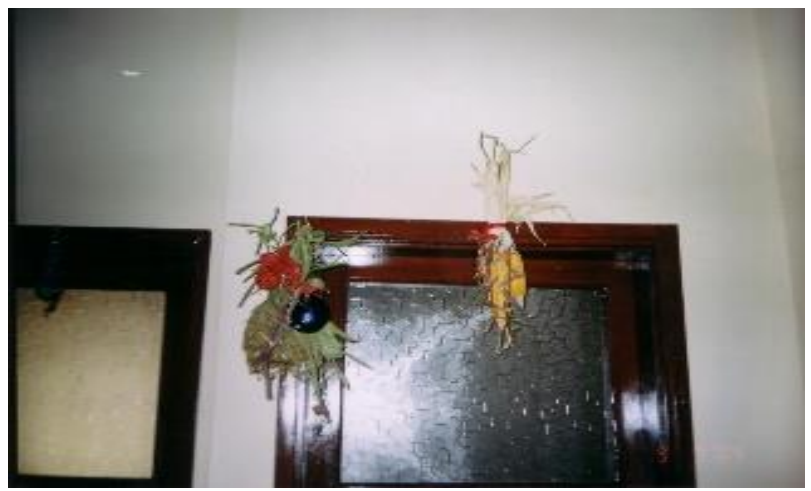

Fotoğraf 5: Yeni doğan çocuğun yattı̆̆ı odanın kapısına asılan soğan ile üzerlik, karaçalı ve diğer nazarlıklar.

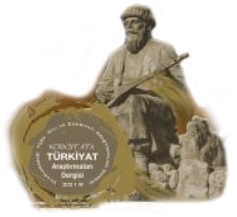




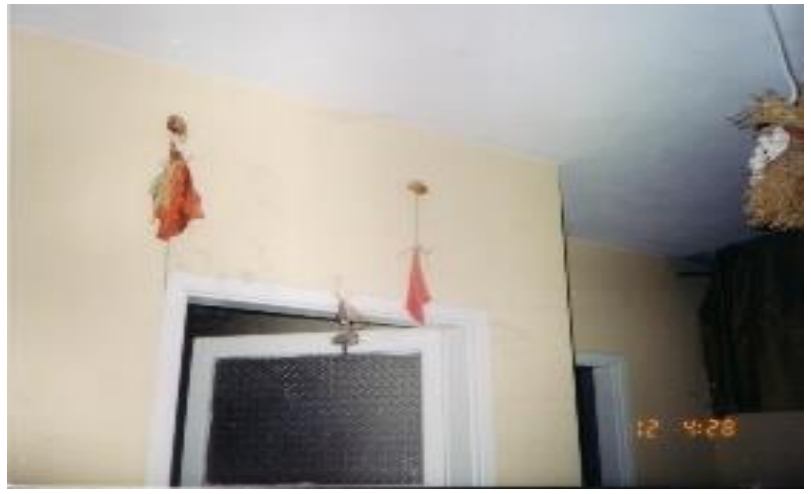

Fotoğraf 6: Eve asılı nazarlıklardan bazıları. Zakkum, karaçalı, nazar boncuğu, darı ve üzerlik.

Kırklamada olduğu gibi bu kısımda da demirin kullanımı görülmektedir. Türk kültüründe demirin koruyucu özelliğe sahip olduğu; hastalara şifa verici, kötü ruhları uzaklaştırıcı ve nazara karşı koruyucu olduğu ve doğadaki bazı gizemli olan diğer varlıklar gibi demirin de gizil güçlere sahip olduğu inancı vardır (Uğur Çerikan 2018: 8).

Köy halkınca bebeğin sürekli ağlaması da kötüye yorulur. Bu durumdaki bebeklere muska yazdırılıp kurşun döktürülür ya da kırklanır (KK 1; 2; 3; 5). Bu durumda yapılan bir diğer uygulama daha vardır. Sürekli ağlayan bebeğin ağzına, üç Cuma günü art arda sabah ezanı okunmadan babasının ayakkabısı ile üç defa vurulur. Böylece bebeğin bir daha ağlamayacağına inanılır (KK 3; 6).

Eskiden bebeğin sesinin güzel olması için sesi güzel olan bir kişiden, bebeğin ağzına tükürmesi istenirmiş (KK 8; 12). Güzel ve kötü sese sahip kişiler için "Senin ağzına X kişisi mi tükürdü? Sesin bu kadar güzel/kötü." denilmesi (KK 8) bu uygulamanın sözel bir kalıntısıdır. Sağlık açısından risk taşıyan bu uygulamanın günümüzde yapıldı̆̆ına dair herhangi bir duyumumuz ya da gözlememiz olmamıştır.

\section{Sonuç}

Adana'da yaşayan Şambayadı Türkmenleri arasında doğum ile ilgili inanç ve uygulamalar ile kaçınmaları ele aldığımız bu incelemede; evlilikten başlayarak bebeğin kırklanmasına kadar geçen süre zarfında hem anne adayı hem de bebeğe yapılan uygulamalar, anne ve bebeğe zarar vereceği düşünülen kötü ruhlar, nazar ve bunlardan korunmak için yapılan uygulamalar ele alınmıştır.

İncelemenin girişinde söz konusu Türkmenler ve köy ile ilgili tarihî ve genel bilginin ardından ilk kısımda bebek sahibi olmak isteyen kadının gebe kalmasında, bebeğin cinsiyetinin belirlenmesinde; ikinci kısımda doğum sırasındaki dinî ve büyüsel işlemlere başvurulduğu görülmüştür. Bu dinî işlemler arasında ocak, türbe ve ziyaret yerlerinde yapılan pratikler, adanan adaklar ve dinle özdeşleştirilen bazı büyüsel işlemler sayılabilir.

Son kısımda ise doğumdan sonra anne adayının; sütünün bol olması, bebeğin rahat uyuması ve sağlıklı gelişimi ile hem anne hem de bebeğin kötü ruhlardan uzaklaştırılması için söz konusu dinî ve büyüsel işlemlere başvurulduğu tespit edilmiştir.

Genel olarak bu inanç ve uygulamaların, gebe kalmadan anne ve bebeğin korunmasına kadar etkili olduğuna, genellikle kadınlar tarafından inanılmaktadır. Günümüzde sağlık sistemindeki ilerleme, birçok uygulamayı azaltsa da bitirememiş bu uygulamaların geçmiş dönemlerde yapıldığını bilen ya da bu işlemlere şahit olan kişiler, doktor gözetiminde aldığ ${ }_{1}$ bir tedavinin yanında hem dinî hem de büyüsel işlemleri, bu tedavinin yanında uygulamaya devam etmişlerdir. Bu bağlamda geçmişten günümüze

Korkut Ata Türkiyat Araştırmaları Dergisi
Uluslararası Türk Dili ve Edebiyatı Araştırmaları Dergisi
The Journal of International Turkish Language E Literature Research
Sayı 5/ Ağustos 2021


kadar yapılan işlemler arasında sadece sağlığa zarar verebileceği düşünülen bazı uygulamaların ertelendiği söylenebilir. Ancak bebeği olmayan bir kadının yapması gereken, her ne kadar sağlık açısından hijyenik olmasa ya da tiksindirici bulunsa da gebe kalabilmek için kesilen bir tavuğun kanını içmek gibi bazı uygulamaların gizli saklı sürdürüldüğü tarafımızdan gözlemlenmiştir. Doğurganlığı ve bereketi sembolize etmesi sebebiyle tavuk ve yumurtası, bu özelliğiyle Anadolu'nun bazı bölgelerinde gerdekten önce gelin ve damada yedirilen yiyeceklerdendir (Örnek 1966: 85; Akalın 1993: 123). Aynı zamanda tavuk ya da horoz, birçok büyü çeşidinde kullanılan hayvanlar arasındadır (Tanyu 1992: 505). Bu uygulama, genellikle büyüyle kısmeti ve bereketi bağlandığ1 düşünülen kişileri çözmek ve zıtlık çağrışımına dayanmakta olup bir şeyi zıddı ile tedavi eden allopatik büyü alanına girmektedir (Örnek 1966: 84). Köyde yapılan bu işlem de bu bağlamda ele alınılabilir ve kendisine yapılan büyü sonucunda gebe kalamadığı düşüncesiyle kadınlar tarafından yapılmaktadır.

Son olarak Adana dışında Adıyaman ve Karaman'da da Şambayadı Türkmenlerinin yerleşik olarak yaşadıklarını söylemiştik. Bu bağlamda inceleme alanı olan Şambayadı Köyü'nde doğum etrafında tespit ettiğimiz bu inanç ve uygulamalar ve kaçınma yolları ile dinî ve büyüsel işlemler, Türkiye'nin diğer bölgelerinde yaşayan Şambayadı Türkmenleri arasında derlenecek veriler ile mukayese edilebilir. Böylece adına "boy folkloru" diyebileceğimiz bir "Şambayadı Boyu Folkloru" çıkarılabilir. Bu sayede günümüze kadar yapılan bölgesel monografi çalışmalarının yanında "boy monografileri" de hazırlanarak halkbilimi çalışmalarına katkı sağlanabilir ve bir boya mensup olan topluluğun, geçmişten günümüze kadar ister dinî isterse büyüsel olsun hangi uygulama ve inançları devam ettirdiği ya da hangilerinden kaçındığı veya hangilerini terk ettiği ve sonradan yerleştikleri bu üç bölgedeki (Adana, Adıyaman, Karaman) coğrafyanın ve diğer toplulukların bu inanç ve uygulamaları nasıl etkilediği incelenebilir.

\section{Kaynakça}

\section{Yazılı Kaynaklar}

Acıpayamlı, Orhan (1974). Türkiye'de Doğumla İlgili Âdet ve İnanmalarn Etnolojik Etüdü. Ankara: Ankara Üniv. Yay.

Acıpayaml1, Orhan (1992). Türk Kültüründe Ad Koyma Folkloru'nun Morfolojik ve Fonksiyonel Yönlerden İncelenmesi. IV. Milletlerarası Türk Halk Kültürü Kongresi Bildirileri, IV, 1-14, Ankara: Ofset Repromat Matbaası.

Akalın, L. Sami (1993). Türk Folklorunda Kuşlar. Ankara: Kültür Bakanlığı Yay.

Aydın, Mehmet (1984). Bayat-Bayat Boyu ve Oğuzların Tarihi. Ankara: Hatiboğlu Yay.

Beydilli, Celal (2004). Türk Mitolojisi Ansiklopedik Sözlük. (Çev.: Eren Ercan). Ankara: Yurt Kitap-Yay.

Boratav, Pertev Naili (1984). 100 Soruda Türk Folkloru (İnanışlar, Töre ve Törenler, Oyunlar). İstanbul: Gerçek Yay.

Drury, Nevill (1996). Şamanizm, Şamanliğın Ögeleri. (Çev. Erkan Şimşek). İstanbul: Okyanus Yay.

Ekici, Metin (2011) Halk Bilgisi (Folklor) Derleme ve İnceleme Yöntemleri. Ankara: Grafiker Yay. 
Ekici, Metin ve Öger, Adem (2007). Türklerde Ocak Kültü ve Bu Kültün Alevilik İnancına Yansımaları. 2. Uluslararası Türk Kültür Evreninde Alevilik ve Bektaşilik Bilgi Şöleni, 2, 1357-1369, Ankara.

Eliade, Mircea (2000). Dinler Tarihine Giriş. (Çev.: Lale Arslan). İstanbul: Kabalcı Yay.

Emeksiz, Abdulkadir (2012). Türk Halk Kültüründe Üzerlik. İstanbul Üniversitesi Edebiyat Fakültesi Türk Dili ve Edebiyatı Dergisi, 28, 229-242.

Ersöz, İsmet (1991). Ashâb-1 Kehf. TDV İslam Ansiklopedisi, 3, 465-467, İstanbul.

Gömeç, Saadettin. (2003). Eski Türk İnancı Üzerine Bir Özet. Tarih Araştırmaları Dergisi, 22 (33) , 79-104.

https://biruni.tuik.gov.tr/medas/?kn=95\&locale=tr (Erişim tarihi: 15.05.2021).

https://sozluk.gov.tr/ (Erişim tarihi: 31.05.2021).

İçli, Ahmet (2013). Türk Kültüründe Ocak Anlayışı ve Ergani Deringöze Köyü'ndeki Bir Ocaklı Aile. Karadeniz Uluslararası Bilimsel Dergi, 1 (18), 95-101.

İnan, Abdülkadir (1962). Albastı-Alkarısı Üzerine Bir Etüd. Türk Folklor Araştırmaları, $7 / 158,2826$.

İnan, Abdülkadir (1986). Tarihte ve Bugün Şamanizm (Materyaller ve Araştırmalar). Ankara: TTK Yay.

İnan, Abdülkadir (1998). Al Ruhu Hakkında. Makaleler ve İncelemeler. Ankara: TTK Yay., 1, 259-267.

Kalafat, Yaşar (1999). Adana ve Çevresinde Türbelerimiz. III. Uluslararası Çukurova Halk Kültürü Bilgi Şöleni (Sempozyumu) Bildirileri, Adana: Adana Valiliği Yay., 409-422.

Kasapoğlu Akyol, Pınar (2020). "Suyla Arınma"dan Modern Zamanların "Gelin Hamamı"na: Tarihi Karacabey Hamamı'nda Gelin Hamamı. Folklor/Edebiyat, 26 (103), 691-706.

Küçük, Abdurrahman (1989). Alkarısı. TDV İslam Ansiklopedisi, 2, 469, İstanbul.

Örnek, Sedat Veyis (1966). Sivas ve Çevresinde Hayatın Çeşitli Safhalarıyla İlgili Bâtıl İnançların ve Büyüsel İşlemlerin Etnolojik Tetkiki. Ankara: Ankara Üniversitesi Basımevi.

Örnek, Sedat Veyis (1973). Budunbilim Terimleri Sözlüğ̈̈. Ankara: TDK Yay.

Örnek, Sedat Veyis (1979). Geleneksel Kültürümüzde Çocuk. Ankara: Türkiye İş Bankas1 Kültür Yay.

Örnek, Sedat Veyis (2000). Türk Halk Bilimi. Ankara: KB Yay.

Refik, Ahmet (1989). Anadolu'da Türk Aşiretleri (996-1200). İstanbul: Enderun Kitabevi.

Sarpkaya, Seçkin (2021). Türklerin Şeytani Masalları, Türk Masal ve Efsanelerinde Demonik Varliklar. Ankara: Karakum Yay.

Sümer, Faruk (1952). Bayatlar. Türk Dili ve Edebiyatı Dergisi, 4(4), 373-398, İstanbul.

Sümer, Faruk (1999). Oğuzlar (Türkmenler), (Tarihleri-Boy Teşkilatı-Destanları). İstanbul: TDAV Yay.

Şimşek, Esma (2017). Türk Kültüründe “Alkarısı" İnancı ve Bu İnanca Bağlı Olarak Anlatılan Efsaneler. Akra Uluslararası Kültür, Sanat, Edebiyat ve Eğitim Bilimleri Dergisi, 5 (12), 99-115.

Korkut Ata Türkiyat Araştırmaları Dergisi
Uluslararası Türk Dili ve Edebiyatı Araştırmaları Dergisi
The Journal of International Turkish Language E Literature Research
Sayı 5/ Ağustos 2021


Tanyu, Hikmet (1992). Büyü. TDV İslam Ansiklopedisi, 6, 501-506.

Uğur Çerikan, Fidan (2018). Türk Kültüründe Demir. Ankara: Grafiker Yay.

Yalman/Yalgın, Ali Rıza (2000). Cenup'ta Türkmen Oymakları II. Ankara: KTB Yay.

Yeşil, Yılmaz (2014a). Türk Dünyasında Geçiş Dönemi Ritüelleri (Doğum-Evlenme-Ölüm Gelenekleri). Ankara: Grafiker Yay.

Yeşil, Yılmaz. (2014b). Türk Dünyası'nda Doğum Sırasında Gerçekleştirilen Ritüeller. 21. Yüzyılda Eğitim ve Toplum Eğitim Bilimleri ve Sosyal Araştırmalar Dergisi, 2 (6) , 155162.

\section{Sözlü Kaynaklar}

KK 1: Mehmet ÖZDAMAR, 1951 doğumlu, ilkokul mezunu, çiftçi.

KK 2: Nermin ÖZDAMAR, 1959 doğumlu, okuma-yazması yok, ev hanımı.

KK 3: Fadime SUNGUR, 1982 doğumlu, ilkokul mezunu, ev hanımı.

KK 4: Sebile ÖZDAMAR, 1974 doğumlu, ilkokul mezunu, ev hanımı.

KK 5: Emine ARIK, 1934 doğumlu, okuma-yazması yoktu, vefat etti.

KK 6: Fatma ÖZDAMAR, 1930 doğumlu, okuma-yazması yoktu, vefat etti.

KK 7: Elveda ÖZDAMAR, 1962 doğumlu, okuma-yazması yok, ev hanımı.

KK 8. Dudu ÖZDAMAR, 1946 doğumlu, okuma-yazması yok, ev hanımı.

KK 9: Uğur ÖLKER, 1984 doğumlu, ortaokul mezunu, çiftçi.

KK 10: Ömüral ÖZDAMAR, 1979 doğumlu, ilkokul mezunu, kaportac1.

KK 11: Hatice TÜRKMEN, 1977 doğumlu, ilkokul mezunu, ev hanımı.

KK 12: Ulviye ÖZMEN, 1965 doğumlu, okuma-yazması yok, ev hanımı.

KK 13: Hayat YENGEL, 1935 doğumlu, okuma-yazması yoktu, vefat etti.

KK 14: Ferdane ÖZMEN, 1975 doğumlu, ortaokul mezunu, ev hanımı. 